\title{
PROFILE
}

The French Greens in the 2012 Presidential and Legislative Elections

Publication details

Environmental Politics, 21/6, November 2012, pp.987-93

doi 10.1080/09644016.2012.724218

http://www.tandfonline.com/doi/abs/10.1080/09644016.2012.724218

GRAEME HAYES

School of Languages and Social Sciences, Aston University, UK

Correspondence address: School of Languages and Social Sciences, Aston University, Aston Triangle, Birmingham B4 7ET, UK

Email: g.a.hayes@aston.ac.uk 


\section{The French Greens in the 2012 Presidential and Legislative Elections}

These are heady times for the French Greens. In the 2009 European elections, Europe Ecologie obtained over 2.8 million votes (16.28\%), and gained as many seats (14) as the Parti socialiste (PS); in the 2010 regional elections, Greens gained $12.18 \%$ of the first round vote, 263 councillors (up from 159 in 2004), and subsequently entered alliances with the PS in the executives of 21 of metropolitan France's 22 regional councils. The dissolution of Les Verts in November 2010 into Europe Ecologie-Les Verts (EELV) was completed in a position of strength. In September 2011, the newly recomposed party confirmed this electoral breakthrough, increasing its membership of the Sénat (the upper house of Parliament, traditionally difficult for Greens because of its rural base and indirect mode of election) from four senators to twelve.

Against this background, the party's performance in the 2012 presidential and legislative elections requires explanation. Eva Joly, the EELV presidential candidate, polled the second lowest score by an official Green candidate since Les Verts was formed in 1984, whilst at the legislative elections EELV candidates polled a bare 5.5\%. Joly's campaign was, according to the press, 'maladroite' (Ouest-France), ${ }^{1}$ a 'fiasco' (Le Monde), ${ }^{2}$ characterised by poor media relations, a confused political line, and internal dissent, with one senior Green, Noël Mamère, wondering in a radio interview five weeks before the election whether Joly shouldn't simply pull out in order to avoid humiliation. Not only did Joly's poll ratings collapse over the course of a long campaign (one poll credited her with 7.5\% during the party's internal primary in June 2011), but so did the party's membership, from 16,452 at the end of 2011 to between 5,000 and 6,000 in June 2012. In policy terms, the campaign was scarcely more successful, with broad Green thematics such as global warming, or the crisis in the renewable energy sector, conspicuously absent from the wider presidential (and legislative) campaigns. Yet EELV finished the legislative elections with 17 députés, enabling it to form an independent group in the Assemblée nationale for the first time, providing access to significant parliamentary rights and resources, increasing its visibility and (potentially) influence. Moreover, two Greens have joined Jean-Marc Ayrault's socialist government: Pascal Canfin as junior minister for International development ('Coopération'); and Cécile Duflot, the party's extremely capable national secretary, as minister for Housing, officially the sixth-ranked member of the government.

\section{The Campaigns: Primary, Presidential, Legislative}

EELV was the first party to choose its candidate for the 2012 presidential elections, holding a two-round national primary in June and July 2011, three months before the PS held its own ballot. Eligible to vote were members of EELV and of Antoine Waechter's Mouvement Ecologiste Indépendant, plus anyone registering as a 'coopérateur' (sympathiser), for which

\footnotetext{
1 'Résultats. L'analyse des scores, candidat par candidat', Ouest-France, 23 April 2012, http://presidentielle2012.ouest-france.fr/actualite/lanalyse-des-scores-candidat-par-candidat23-04-2012-1140

2 'Chronique d'un fiasco', Le Monde, 19 April 2012, p.18.

${ }^{3}$ Figures from national party secretary Cécile Duflot, 30 December 2011, https://twitter.com/cecileduflot/status/152786758797496320, and 'A EE-LV, un bureau très exécutif pour Duflot', Libération, 22 June 2012.
} 
one had to sign up to the principles of the Global Greens Charter. In all, this made an electorate of around 33,000 supporters. The two main candidates were Joly and Nicolas Hulot. Joly is a Franco-Norwegian citizen with a remarkable biography: having arrived in France as an au pair in the early 1960s, she settled, formed a trades union whilst working as a secretary, married, studied law and political science, qualified as a magistrate, became a juge d'instruction, and successfully prosecuted the ELF trial in the mid-1990s (which remains France's highest profile corruption trial), before joining EELV in 2008 and being elected MEP in June 2009. Hulot is a television presenter on the commercial TF1 channel, president of the environmental NGO Fondation Nicolas Hulot, and originator of the Pacte écologique, which inspired President Nicolas Sarkozy’s Grenelle de l'environnement (the nationwide environmental policy consultations which, for many Greens, seriously undermined the party's presidential campaign of 2007 whilst ultimately delivering little of substance).

Media-friendly and dynamic, Hulot gained support from many of EELV's leading figures as the candidate most likely to broaden the party's appeal, and was widely expected to win. However, the party base was considerably more sceptical than the leadership; Hulot's green capitalism, and especially his personal relationship with major transnational corporations his NGO is financed by corporate sponsorship deals with TF1, EDF and L'Oréal - was a problem for many. Hulot's fate was sealed when, during an evidently good dinner with journalists, he discussed his closeness to Sarkozy's former environment minister, Jean-Louis Borloo - and let slip that he had initially envisaged a joint ticket for the 2012 presidential election with the centre-right politician. The admission was a gift for Joly; five weeks later, she trounced Hulot by $58.16 \%$ to $41.34 \%$ in the second round run-off. Hulot did not take this well, retreating to his NGO, claiming betrayal, and refusing to back Joly.

But if Hulot's failing in the party was his excessive flexibility, Joly's own failing was her inflexibility. In November 2011, EELV negotiated an electoral and programmatic agreement with the PS. Joly, along with leading figures in EELV, insisted that there would be no agreement unless it included cancellation of both a new international airport at Notre Dame des Landes (north of Nantes), and the vastly over-budget EPR nuclear reactor at Flamanville, Normandy. When the PS didn't blink, EELV was forced to accept a compromise, which included notice of non-agreement between the parties on these projects and on electoral reform to introduce proportional representation for future legislative elections.

For the party leadership, this was the inevitable compromise of politics, and, though difficult to swallow, did not invalidate a vital agreement. Joly, however, had built her entire life personal, professional, political - on integrity in the face of expediency, and trust in her own values and resources to defeat institutional obfuscation. In the following fortnight, Joly refused first to attend the party's committee meeting ratifying the agreement, and then to commit herself to backing François Hollande in a potential second-round election duel with Sarkozy. From that point, Joly found herself increasingly isolated by leading figures within EELV, fighting the campaign at times almost alone, the candidate of a party that had already moved on to the more important business of the legislative elections.

We can see Joly's inflexibility as the product of personal style, but also of party calculation. In the primary, Joly described her difference from Hulot as a choice between an écologie de combat and an écologie de consensus; during her presidential campaign, combativeness was a defining feature as she set out a clearly left-wing agenda rarely tied to environmental thematics. Most prominently, Joly's campaign was constructed around her status as an outsider, both with respect to the political system (with strong emphasis on corruption, fraud, 
tax havens, and very personally, on Sarkozy's proximity to the Bettencourt and Karachi kickback affairs) and to dominant national cultural dispositions, questioning some of the more illiberal manifestations of French Republicanism (advocating the replacement of the militaristic $14^{\text {th }}$ July parades with a new citizen's celebration; proposing two new public holidays, one Jewish, one Muslim; revealing that her grandchildren's nanny wears a hijab, and so on). More traditional environmental proposals - a carbon tax or the reduction of pesticide use by $50 \%$ within five years - were given much less prominence.

Where environmental themes did become central to the campaign, it was rarely due to Joly herself. France's nuclear power programme emerged as a key issue in the final weeks before the election, but only tangentially as a debate over energy policy or climate mitigation. Rather, nuclear was primarily a cipher for an argument over presidential character, with Sarkozy and Hollande each seizing the issue to play on public perceptions of the other's supposed personal weaknesses. 'N'est pas François Mitterrand qui veut', mocked Sarkozy of his rival at a rally in Caen in early April, contrasting the determination and vision of De Gaulle and Mitterrand with Hollande's apparent lack of authority and willingness to parlay France's energy independence and security for an electoral agreement with an ideologically intransigent party whose candidate stood at $1.5 \%$ in the polls. Hollande countered by turning the issue into one of Sarkozy's ego-driven hyper-presidentialism: when Sarkozy claimed to have been the first world leader to visit Fukushima following the accident, when he had in fact been no nearer than Tokyo, this was simply another obvious example of the man's selfaggrandising mendaciousness.

Lost in this clash of antlers was reasoned debate over climate change and energy transition. Joly was hemmed in by the party's agreement with the PS, which she had refused to endorse. Under the agreement, France's oldest nuclear plant, at Fessenheim in Alsace, would be decommissioned (ostensibly because of potential seismic risk), whilst nuclear's share of electricity production would be reduced from $75 \%$ to $50 \%$ by 2025 , the shortfall to be met by renewables. Hollande, far from anti-nuclear, declared that only Fessenheim would close, and that the nuclear industry remained safe in his hands. Joly was also frequently outflanked by the charismatic Jean-Luc Mélenchon, candidate of the Front de Gauche. Mélenchon advocated a form of long-term ecological planning and a national referendum on nuclear power, thereby attracting many potential Green voters whilst maintaining the support of his Communist base and conjuring the spirit of Mitterrand's 1981 campaign proposals. Numerous eco-socialist figures rallied to Mélenchon, his speech in January to a special congress called by France Nature Environnement earning an enthusiastic reception.

Following Hollande's victory, the parliamentary vote took place amidst widespread apathy. On the right, the main candidates to claim Sarkozy's mantle as Gaullist leader seemed more intent on jockeying for position than with leading a national election campaign. On the left, the President had nominated his Prime minister, and the government had been making policy statements and passing decrees for three and a half weeks before the first round of the legislative elections had even taken place. This confusion of coaches and horses clearly reinforces the primacy of the president over the government, and produced an election campaign of little incident, with not a single major televised debate before the first round. Headlines were grabbed only by ego-driven confrontations: between Mélenchon and Front National leader Marine Le Pen and, memorably, via Twitter, between Hollande's current and former companions, Valérie Trierweiler and Ségolène Royal. The abstention rate was the highest for a legislative election under the Fifth Republic (42.78\% on the first round, $44.59 \%$ 
on the second), comparing particularly badly with the preceding presidential election (20.52\% first round, $19.66 \%$ second).

\section{Results}

Compared to previous official Green candidacies, Joly’s 2.31\% was better only than Dominique Voynet's 1.57\% in 2007. Joly exceeded 5.5\% in three constituencies in Paris, and in five of the new constituencies established for French nationals worldwide; in these eleven 'foreign' constituencies combined, Joly polled 5.44\%. In mainland France, Joly's scores were relatively strong in the west, particularly Brittany, and in the east (Alsace, Jura, Doubs) and southeast (Savoie, the Alpes), and weak in the centre, north and north-east.

The Joly vote reflects the historic, place-based embedding of environmental movement campaigns and peripheral regional identities, but results from the constituencies outside France underline the mobility of the Joly vote, and those from the major French cities its predominantly urban nature (see Table 1.)

\begin{tabular}{|c|c|c|}
\hline City & Population & Joly vote (\%) \\
\hline Paris & 2590000 & 4.18 \\
\hline Marseille & 889000 & 2.15 \\
\hline Lyon & 527000 & 4.09 \\
\hline Toulouse & 371000 & 4.32 \\
\hline Nice & 322000 & 1.97 \\
\hline Nantes & 260000 & 4.61 \\
\hline Strasbourg & 249000 & 4.19 \\
\hline Montpellier & 162000 & 3.90 \\
\hline Bordeaux & 267000 & 4.00 \\
\hline Lille & 238000 & 3.90 \\
\hline Total & 5875000 & 3.74 \\
\hline
\end{tabular}

Table 1. Percentage of the vote gained by Eva Joly in the first round of the 2012 Presidential election in the ten most populous French cities.

Source : http://www.linternaute.com/ville/ville/elections-presidentielles/21605/lille.shtml

An IPSOS/Logica (2012) poll on the eve of the presidential election found that Joly's electors were marginally more likely to be women than men, much more likely to be under than over 35, disproportionately highly educated and liberal professionals, and non-Catholic.

Under the terms of the agreement between the parties, EELV's candidates for the legislative elections were unopposed by the PS in 63 constituencies. EELV stood 471 candidates in all, averaging 5.46\%; 40 candidates survived to the second. Seventeen were elected, ${ }^{4}$ far fewer than EELV expected when it concluded the deal with the PS, its under-performance mostly

\footnotetext{
${ }^{4}$ Duflot did not take her seat, as it is not possible to be both a (national) parliamentarian and a government minister. The parliamentary group nonetheless remains at 17 , as it was joined by a Breton regionalist. Canfin, the other Green minister, is an MEP and did not stand in the legislative elections.
} 
explained by a large number of dissident socialists who rejected party orders to stand aside; without these dissident candidacies, EELV could have expected to win around 30 seats. However, EELV candidates averaged only 3.9\% in the 400 constituencies where they stood without PS backing.

\section{Discussion}

What lessons can be drawn? I explained Joly's poor performance in terms of four factors: an inflexible candidate, an incoherent campaign, an inspired competitor (Mélenchon), and the inhospitable electoral system. Of course, this (or something similar) could be said of almost every previous Green presidential campaign, played out as a battle over the direction and character of the party against the backdrop of personal and ideological divisions. In this case, however, another story emerges, of flexibility, and of the party's adaptation to its political and institutional environment. For French Greens, there is a dissonance between a highly participatory internal culture and a collective commitment to faire de la politique autrement, and the demands of personalised presidential politics and, in a majoritarian electoral system, the requirement to make alliances with established parties in order to gain parliamentary representation.

What sets this apart from previous campaigns is that the battle over the direction of the party was settled elsewhere, the decision already taken in the agreement between PS and EELV. In spite of Joly's poor result, these campaigns reveal the extent of the Greens' adaptation to the rules of the game. This was the third time that the Green candidate was chosen in a primary contest but, whereas previous contests offered electors choice between representatives of competing tendencies, here the choice was between two candidates whose political capital was principally their status as crusading personalities, as individuals able to produce social change through personal example. Potentially problematic for the party, this was liberating for the leadership. Even as Joly's campaign neared collapse, it continued to emphasise a key characteristic of the Greens: the importance of ethical commitment, the refusal of political 'langue de bois' (empty rhetoric), their fundamental difference from the institutional parties. The leadership was able simply to sacrifice the presidential campaign, to write it off as shortterm collateral damage, and shift resources to safeguarding the agreement all but guaranteeing the party a parliamentary group.

The contrast between EELV and the Front de Gauche is instructive. EELV accrued substantial electoral capital from its remarkable success in the 2009 and 2010 European and regional elections. Negotiating early with the PS from a position of strength, it chose to cash in this capital for an agreement over constituencies, abandoning programmatic demands in order to secure highly favourable terms. EELV's legislative campaign was thus inoculated from the potential failure of its presidential candidate. In contrast, negotiating after the presidential elections on the back of Mélenchon's 11.1\%, the Front de Gauche was unable to reach agreement with the PS and EELV, securing a handful of extra constituencies where its candidates would run unopposed against the right and extreme right. Despite increasing its share of the vote, the Front de Gauche saw its parliamentary seats cut from 19 to ten.

\section{Conclusion and Prospects}


The Joly campaign privileged an oppositional cultural agenda over a more tightly focused series of policy thematics. This was, perhaps, an inevitable consequence of the candidate's own personality and, presentationally, her harsh and strongly accented voice: Joly was widely seen (or heard) as an unsympathetic, hectoring, chiding figure, holding the French to account for their error-strewn ways, at odds with a presidential cultural narrative of La France éternelle. But this oppositional character was also a consequence of the PS-EELV agreement: cultural opposition was one of the few areas open to Joly to stress her difference from the mainstream whilst not entering into open criticism of the PS, and thus undermining the two parties' agreement for the parliamentary elections. In raw percentage terms, the outcomes of both elections are undeniably poor; but in context, they are surely more successful. The French Greens have never enjoyed high scores in presidential elections nor previously been close to forming a parliamentary group, and one may be sceptical as to how many more parliamentary seats a more overtly competent presidential campaign would have produced given the lack of internal party discipline in the PS. Meanwhile, Duflot herself may develop into a serious politician of national standing, her position as housing minister will enable the Greens to raise the profile of their social justice and redistributional agendas, and she can regard her tenure as party secretary as successful, reforming the party's internal statutes and fighting a series of successful campaigns.

Yet this is a definition of success that sees politics in terms of the hierarchical organisation and distribution of places and functions; the democratic challenge to such hierarchies in the name of the collective commons has been secondary. Having spent the entirety of the capital it accrued from the European and regional elections, the failure of EELV to make much headway on its key themes, its newfound and evident readiness to abandon programmatic principle for strategic calculation, and the collapse in membership numbers over the first six months of 2012, may have far more serious consequences for the party than Joly's result. Hollande is not known for his espousal of environmental causes, to put it mildly, whilst the appointment of socialist Nicole Bricq to the environment ministry, followed by her immediate re-assignment to international development - apparently following intense oil industry lobbying after Bricq suspended exploration permits off French Guyana ${ }^{5}$ - suggests a rocky road ahead.

\section{References}

IPSOS/Logica (2012), $1^{\text {er }}$ tour présidentielle 2012. Comprendre le vote des Français, Paris, Ipsos Public Affairs.

\footnotetext{
5 'Comment la pétrole de la Guyane a eu raison de la ministre de l'écologie', Le Monde, 22 June 2012.
} 